\title{
Antitumor activities and immunological studies with algal polysaccharides
}

\author{
HIROKO ITOH, HIDEOMI AMANO, MAKOTO KAKINUMA, AND HIROYUKI NODA \\ Laboratory of Marine Biochemistry, Faculty of Bioresources, Mie University, Tsu, Mie 514-8507, \\ Japan
}

SUMMARY: The antitumor effect of $G I V-A$ (fucoidan) and/or 5-FU was examined in an experimental model of lung metastases induced by Lewis lung carcinoma (3LL) or Ehrlich ascites carcinoma (EAC) in mice. Combination treatment with $G \mathrm{IV}-\mathrm{A}$ and 5-FU incresased significantly antitumor activity. In the group receiving G IV -A, the percentages of splenic Thy 1.2-, L3T4- and asialo GM1-positive cells were significantly increased as compared with the tumor-bearing mice treated with saline. Furthermore, the $\mathrm{L} 3 \mathrm{TH} 4^{+} / \mathrm{Ly} \mathrm{t} 2^{+}$ratio showed a tendency to increase, and the Lyt2 ${ }^{+} /$Thy $1.2^{+}$ratio was decreased. These results suggest that the antitumor effect of $G N-A$ may be correlated with the changing pattern of the Thy1.2-, L3T4- and asialo GM1-positive cells, the third component of complement $\mathrm{C} 3$ activation, and macrophage activation.

\section{KEY WORDS: seaweed, fucoidan, immune response, antitumor activity}

\section{INTRODUCTION}

Antitumor drugs with direct cytotoxic or cytostatic effects on tumor cells commonly have side effects as well such as gastrointestinal and bone-marrow disturbances or hepatic and blood toxicity. These drugs also suppress imune responses. On the cotrary, recently biological response modifiers like antitumor drugs have been developed in Japan. These antitumor drugs are Krestin, or PSK obtained from mycelium of Kawaratake (Coriolus versicolor), Lentinan from fruiting bodies of Shitake (Lentinus edodes) and Schizophyllan a product from the medium of Suehirotake (Shyzophyllum commune).

Certain seaweeds have long been used in traditional Chinese herbal prescriptions for the treatment of malignant tumors. In 1974, Yamamoto et al 1,2) reported that Sargassum fulvellum, $S$. kjiellmanianum, Laminaria angustata, and $L$. angustata var. longissima, markedly inhibited the growth of Sarcoma-180 implanted subcutaneously in mice, and each fraction was found to consist primarily of polysaccharide. On the other hand, Nakazawa et al 3) also demonstrated that a sulfonic acid group-rich fraction from Sargassum horneri showed antitumor activity against EAC in mice. Several sulphated polysaccharides have been used experimentally as antimetastatic agents. ${ }^{4-6)}$ Harada et al ${ }^{7)}$ previously reported that methanol extracts of 47 species of marine algae from Japan's coasts was biologically active in vitro selective antitumor activity against several tumor cell lines.

In 1975, we examined the effects of 12 kinds of marine algae from the Sargassum group on the growth of EAC in mice. In particular, strong antitumor activity was seen in Sargassum thunbergii (Japanese name "Umitoranoo"). After the pre-treatment of $\mathrm{EtOH}$, the polysaccharides fraction were isolated from a hot-water extract of Umitoranoo by ethanol precipitation, ion-exchange chromatography and gell-filtration. A total of 32 polysaccharides were tested an antitumor activities against EAC. ${ }^{8)}$ Especially, GIV-A fraction was most effecive. GIV-A is fucan sulfate (fucoidan) of molecular weight 19,000 containing $10.4 \%$ uronic acid, $1.6 \%$ protein and $28.2 \%$ fucosyl $-\mathrm{OH}$ ester sulfate, judging from analyses of IR- and ${ }^{13} \mathrm{C}$-NMR-spectra. ${ }^{9}$ )

The present studies were undertaken to examine the antitumor effects of G IV-A on the growth of EAC, $3 \mathrm{LL}$ and the inhibition of lung metastasis. In addition, the phagocytosis of macrophages, the alterations of complement C3, and the influence of the splenic lymphocyte subsets was discussed.

\section{MATERIALS AND METHODS}

\section{Animals}

Five-week-old female C57BL/6CrSLC mice (SPF) and ICR/Slc mice were obtained from Shizuoka Laboratory Animal Center (Japan).

\section{Tumor cells}

EAC was initially supplied by the National Cancer Center Research Institute, Tokyo, Japan. 3LL cells were kindly provided by Dr. H. Nakanishi, M.D. ${ }^{10)}$ Aichi Cancer Center Institute (Japan).

\section{Chemicals}

G IV -A was prepared accoding to the methods previously reported for the purification. ${ }^{9)}$

\section{Evaluation of antitumor activity}

EAC cells were inoculated intraperitoneally (i.p.) into the mice. Treatment was initiated $24 \mathrm{hrs}$ after tumor inoculation. For the 3LL system, the test 
samples were injected i.p. three times a week, starting 24 hrs after tumor implantation. As for the lung metastases system, 3LL cells were implanted s.c. into one footpad of each mouse. ${ }^{11}$ )

\section{The $\mathrm{C} 3$ cleavage product binding assay}

Eight-week old female mice were injected i.p. with zymosan, GIV-A. The percentage of C3-positive fluorescent cells was calculated by counting of 200 adherent cells. ${ }^{12)}$

\section{Analysis of splenic T-lymphocyte subsets}

GIV-A was given i.p. at a daily dose of $20 \mathrm{mg} / \mathrm{kg}$ three times a week for 2 weeks. The suspension of spleen cells were added monoclonal antibody. The cell suspension was analyzed by flow cytometry. ${ }^{13)}$

\section{RESULTS}

EAC are considered to be rapid growing tumors. So we examined antitumor effect of G IV-A against $\mathrm{EAC}$. In $20 \mathrm{mg} / \mathrm{kg}$ treated group, the growth of the tumor was suppressed in all of the mice examined and the complete regression of tumor was obsarved in 5 out of 8 mice (Table 1). To investigate the antitumor mechanism of G IV-A, EAC cells were obtained from the peritoneal cavity in mice. After the incubation, the cells were stained with FITC-labeled G N-A and examined under a Fluorescence microscope. EAC cells have the receptor which specifically bind to G IV-A (data not shown). Therefore, continued ability to bind $G$ IV-A on the EAC cell membrenes could play an important role in the antitumor response. ATSO and Picibanil showed no antitumor activity. While 5-FU was markedly active, causing an increase in life-span of $65.6 \%$ as controls. However, the median survival time of mice treated with 5-FU was shorter than that of G IV-A.

Recently, lung cancer is increased significantly in Japan. Then we examined the antitumor effect of GIV-A and 5-FU on $3 \mathrm{LL}$. In the group receiving $\mathrm{G}$ IV-A $20 \mathrm{mg} / \mathrm{kg}$, marked suppression of tumor growth was seen ( Table 2). The tumor inhibition ratio of the GIV-A treated group relative to the saline-treated control group was $81.0 \%$. Antitumor activity of GIV-A varied according to the dose.

$5-F U 30 \mathrm{mg} / \mathrm{kg}$ was markedly active. However, the antitumor effect of $50 \mathrm{mg} / \mathrm{kg}$ with $5-\mathrm{FU}$ was weaker than that of the control group because of 5-FU toxicity.

The inhibition and prevention of metastasis are important problems in cancer therapy. We used $3 \mathrm{LL}$ as an experimental model. An optimal dose of G IV -A 20 $\mathrm{mg} / \mathrm{kg}$ and $5-\mathrm{FU} \quad 30 \mathrm{mg} / \mathrm{kg}$ was administered i.p. As shown in Table 3, the development of lung metastases was inhibited. Combination treatment with G IV-A plus 5-FU significantly decreased the mean number of
Table 1. Antitumor effects of some preparations on EAC

\begin{tabular}{lccc}
\hline Treatment & \multicolumn{2}{c}{ Mean survival time } & $\begin{array}{c}\text { Tumor-free mice } \\
\text { on day } 30\end{array}$ \\
\cline { 2 - 3 } & \multicolumn{1}{c}{ Days } & $\%$ & \\
\hline Saline & $15.1 \pm 1.5$ & 100 & $0 / 10$ \\
G N-A & $52.6 \pm 11.3^{*}>348.3$ & $5 / 8$ \\
ATSO & $15.7 \pm 2.3$ & 103.9 & $0 / 10$ \\
Picibanil & $18.3 \pm 1.9$ & 121.2 & $0 / 10$ \\
5-FU & $25.0 \pm 4.4^{*}>165.6$ & $1 / 10$ \\
\hline
\end{tabular}

G IV-A (20 mg/kg), ATSO (100 $\mathrm{mg} / \mathrm{kg})$, picibanil (2 $\mathrm{KE} / \mathrm{kg}$ ) or $5-\mathrm{FU}(20 \mathrm{mg} / \mathrm{kg})$ on days 1 to 10 . Survival time of the treated group expressed as a percentage of survival time of the controls. Values indicate the mean \pm S.E. of 8 to 10 mice. ${ }^{*} \mathrm{P}<0.05$ compared with control group.

Table 2. Antitumor effects of G $\mathrm{V}-\mathrm{A}$ and 5-FU on 3LL

\begin{tabular}{lccc}
\hline $\begin{array}{c}\text { Treatment } \\
(\mathrm{mg} / \mathrm{kg} / \text { day) }\end{array}$ & $\begin{array}{c}\text { Average weight } \\
\text { of tumor }(\mathrm{g})\end{array}$ & $\begin{array}{c}\text { Tumor inhibition } \\
\text { ratio (\%) }\end{array}$ \\
\hline G IV-A & 10 & $4.3 \pm 2.1^{*}$ & 25.9 \\
& 20 & $1.1 \pm 0.7^{*}$ & 81.0 \\
5-FU & 50 & $2.6 \pm 1.7^{*}$ & 55.2 \\
& 10 & $4.1 \pm 2.2^{*}$ & 29.3 \\
& 30 & $1.6 \pm 0.9^{*}$ & 72.4 \\
Control & 50 & Toxic & \\
\hline
\end{tabular}

Values are indicated as means \pm S.E. of 9 mice. Significant difference: ${ }^{*} \mathrm{P}<0.05$, as compared with the control group.

metastatic nodules visible in the lung. No metastatic nodules were seen in 4 of the 10 mice treated with GIV-A plus 5-FU.

The infectious microorganism can be removed about $99 \%$ by epithelial surface membranes, complement, macrophages and leucocytes, cytokines, as humoral immunity. We examined the effect of $G I V-A$ on human complement system. The $\mathrm{C} 3$ conversion activity of human serum treated with G IV-A was assayed by crossed immunoelectrophoresis. We found that the antitumor activities of ATSO, Zymosan and G N $-A$ is mediated through the activation of complement $\mathrm{C} 3$ by the alternative pathway.

Next, we examined the effect of G IV-A on macrophages (Table 4). The C3-positive macrophages in the peritoneal cavity were observed 2 hours after i.p.. The $67.5 \%$ macrophages were most brightly immunofluorescen positive cells by $G$ IV-A. The enhanced phagocytosis is probably related to $\mathrm{C} 3$ activation by $\mathrm{G}$ IV-A.

Activated adherent peritoneal exudate cells were collected from mice after intravenously injection of $G I V-A$. Activated-macrophages significantly reduced the number of lung metastatic nodules (data not shown). These results indicate that activated-macrophages alone inhibited the development of lung metastasis. Macrophages are found in the reticuloendthelial organs such as liver, spleen, tymus, lymphoid tissue and bone marrow. 
Table 3. Antitumor effects of G IV - A and/or 5-FU on lung metastases

\begin{tabular}{|c|c|c|c|c|c|c|}
\hline \multirow{2}{*}{$\begin{array}{l}\text { Experimental } \\
\text { group }\end{array}$} & \multicolumn{2}{|c|}{$5-\mathrm{FU}$} & \multicolumn{2}{|c|}{ G IV - A } & \multicolumn{2}{|c|}{ Lung metastases } \\
\hline & $\begin{array}{c}\text { Dose } \\
\text { (mg/kg/day) }\end{array}$ & $\begin{array}{c}\text { Day of } \\
\text { injection }\end{array}$ & $\begin{array}{c}\text { Dose } \\
\text { (mg/kg/day) }\end{array}$ & $\begin{array}{l}\text { Day of } \\
\text { injection }\end{array}$ & No. of surface & $\begin{array}{l}\text { Incidence } \\
\text { nodules }\end{array}$ \\
\hline Control & & & & & $31.5 \pm 8.7$ & $10 / 10$ \\
\hline$G I-A$ & & & 20 & $10,12,14,16,18$ & $15.7 \pm 5.1$ & $9 / 10$ \\
\hline $5-\mathrm{FU}$ & 30 & $10,12,14,16,18$ & & & $10.6 \pm 4.9^{*}$ & $7 / 10$ \\
\hline $\mathrm{G} N-\mathrm{A}+5-\mathrm{FU}$ & 30 & $10,12,14,16,18$ & 20 & $10,12,14,16,18$ & $5.3 \pm 3.2^{*}$ & $4 / 10$ \\
\hline
\end{tabular}

Incidence are given as the ratio of number of mice with metastases/number of mice tested. Values are indicated as means \pm S.E. of 10 mice. Significant difference: ${ }^{*} \mathrm{P}<0.05$, as compared with control group (undergoing amputation); ${ }^{*} \mathrm{P}<0.05$, as compared with use of $5-\mathrm{FU}$ or G IV -A alone.

Table 4. Enhancing effects of G IV-A, ATSO, zymosan or dextran on chemiluminescence and induction of $\mathrm{C} 3$-positive macrophages

\begin{tabular}{lcc}
\hline \hline Treatment & $\begin{array}{c}\text { Maximum of } \\
\text { chemiluminescence }\end{array}$ & $\begin{array}{c}\text { C3-positive } \\
\text { fluorescent cells (\%) }\end{array}$ \\
\hline Dextran & $0.05 \pm 0.02(1.0)$ & $18.0 \pm 3.5^{*}$ \\
GIV-A & $0.31 \pm 0.09(6.2)^{*}$ & $67.5 \pm 9.9^{*}$ \\
ATSO & $0.40 \pm 0.18(8.0)^{*}$ & $72.9 \pm 7.5^{*}$ \\
Zymosan & $0.24 \pm 0.15(4.8)^{*}$ & $65.2 \pm 5.7^{*}$ \\
\hline
\end{tabular}

Maximum chemiluminescence and C3-positive fluorescent cells were measured at 2 hours after treatment with 20 $\mathrm{mg} / \mathrm{kg}$ of G N-A, ATSO, zymosan and dextran (control). Values indicate the mean \pm S.E. of 5 mice. ${ }^{*} \mathrm{P}<0.05$ compared with control group. Number in parenthese shows times values to that of control.

And macrophages have phagocytic action. We demonstrated that GIV-A ATSO and Picibanil markedly increased the phagocytic activity and $\mathrm{K}$-index than that of the control mice. Thus, G IV -A acts as a so-called stimulator of the reticuloendotherial system ( RES)

We also examined the effect of G IV-A on splenic T-lymphocytes subsets. Generally, Thy1.2-positive cells are known as a marker of pan $\mathrm{T}$ cells. L3T4-positive cells are regarded as a marker of helper/inducer T cells. Asialo GM1-positive cells are known to be NK cells and activated macrophages. In the group receiving G IV-A, the percentages of Thy1.2-, L3T4- and asialo GM1-positive cells were maintained at higher values than in the tumor-bearing control group (Table 5).

\section{DISCUSSION}

Many plant polysaccharides, as biological response modifiers exert suppressive effects against solid tumors in mice, and their action is considered to be a host-mediated immune mechanism. However, these polysaccharides were ineffective against the ascites form and spontaneous tumors. We found that GIV-A showed antitumor effect against EAC

Table 5. Analyses of splenic Thy 1.2-positive cells, L3T4-positive cells, Asialo GM1-positive cells and Lyt2-positive cells after i.p. administration with $\mathrm{G} I \mathrm{~V}-\mathrm{A}$

\begin{tabular}{|c|c|c|c|}
\hline & \multicolumn{3}{|c|}{ Percentages of positive cell $(\%)$} \\
\hline & \multirow{2}{*}{$\frac{\text { Normal mice }}{\text { Saline }}$} & \multicolumn{2}{|c|}{ Tumor-bearing mice } \\
\hline & & Saline(Control) & G IV - A \\
\hline $\begin{array}{l}\text { Thy 1.2-positive cells } \\
\text { (pan T cells) }\end{array}$ & $50.2 \pm 2.7(100)$ & $\begin{array}{c}32.2 \pm 1.9(64.1)^{*} \\
{[100]}\end{array}$ & $\begin{array}{c}46.9 \pm 1.8(93.4) \\
{[145.7]^{\sharp}}\end{array}$ \\
\hline $\begin{array}{l}\text { L3T4-positive cells } \\
\text { (helper/inducer T cells) }\end{array}$ & $29.9 \pm 3.0(100)$ & $20.2 \pm 1.8(67.6)^{*}$ & $\begin{array}{c}28.7 \pm 1.9(96.0) \\
{[142.1]^{*}}\end{array}$ \\
\hline $\begin{array}{l}\text { Asialo GMl-positive cells } \\
\text { (NK cells and activated } \\
\text { macrophages) }\end{array}$ & $12.1 \pm 1.9(100)$ & $\begin{array}{c}12.3 \pm 0.8(101.7) \\
{[100]}\end{array}$ & $\begin{array}{c}15.9 \pm 0.9(131.4)^{*} \\
{[129.3]^{*}}\end{array}$ \\
\hline $\begin{array}{l}\text { Lyt2-positive cells } \\
\text { (cytotoxic/suppressor } \\
\text { T cells) }\end{array}$ & $12.3 \pm 1.4(100)$ & $\begin{array}{c}8.6 \pm 0.7(69.9)^{*} \\
{[100]}\end{array}$ & $\begin{array}{c}10.5 \pm 0.6(85.4) \\
{[122.1]}\end{array}$ \\
\hline
\end{tabular}

Values are indicated as means \pm S.E. of ten mice. Significant difference: ${ }^{*} \mathrm{P}<0.05$, as compared with saline-treated normal mice; ${ }^{*} \mathrm{P}<0.05$, as compared with saline-treated tumor-bearing mice. 
and $3 \mathrm{LL}$ to inhibit development of the lung metastasis. GIV-A significantly augmented the binding of $\mathrm{C} 3$ cleavage product to peritoneal macrophages and the proportion of $\mathrm{C} 3$ positive cells. Since the enhancement of both phagocytosis and binding of $\mathrm{C} 3$ cleavage product was caused by administration of $G I V-A$, the enhanced phagocytosis is probably related to $\mathrm{C} 3$ activation. On the other hand, it has been shown that some polysaccharides and zymosan ATSO or G IV-A activates an alternative pathway of the complement system.

In the group receiving $\mathrm{G} \mathrm{IV}-\mathrm{A}$, the $\mathrm{L} 3 \mathrm{~T}_{4}{ }^{+} /$ $\mathrm{Ly} 12$ + ratio showed a tendency to increase, and the Lyt $2^{+} /$Thy $1.2^{+}$ratio was decreased. These results are likely to suggest a decrease in Lyt2-positive cells, which are regarded as a marker of suppressor $\mathrm{T}$ cells. This seems to be favorable for cancer immunotherapy.

Tanaka et $a l^{14}$ ) concluded that a novel glycoprotein obtained from Chlorella vulgaris strain CK22 (CVS) showed antimetastatic immunopotentiation though $\mathrm{T}$ cell activation in Lymphoid organs.

The above data leads us to the speculation that the antitumor action of G N-A may be correlated with the activation of complement $\mathrm{C} 3$, macrophages action, stimulation of RES, and the productive abilities of splenic pan T cells, NK cells and helper/inducer $\mathrm{T}$ cells. In summary, it is conceivable that GIV-A has immunostimulating effects and immunomodulatory effects. The results at least indicate that some algal polysaccharides might be a valuable host-mediated preparations in the combination modalities in cancer treatment.

\section{ACKNOWLEDGMENTS}

The author express appreciation to Mr. Toshimitu Sumiya, Director of Iwade Research Institute of Mycology, Tsu, Mie for kindly providing Sargassum thunbergii.

\section{REFERENCES}

1. Yamamoto I, Nagumo $T$, Yagi $K$, Tominaga $H$, Aoki M. Antitumor effect of seaweeds, 1. Antitumor effect of extracts from Sargassum and Laminaria. Jpn. J. Exp. Med. 1974; 44: 543-546.

2. Yamamoto I, Nagumo T, Takahasi M, Fujihara $M$, Suzuki $Y$, lijima N. Antitumor effect of seaweeds, 3. Antitumor effect of an extract from Sargassum kjellmanianum. Jpn. J. Exp. Med. 1981; 51: 187-189.

3. Nakazawa S, Kuroda H, Abe T. Antitumor effect of seaweeds. Proc. Jpn. Cancer Ass. The 33rd Ann Meet 1974; 103.

4. Tsubura E, Yamashita T, Kobayashi M, Higuchi $Y$, Isobe J. Inhibitory mechanism of blood-borne pulmonary metastasis by sulfated polysaccharides. Gann Monogr. Cancer Res.
1977; 20: 147-161.

5. Coombe DR, Parish CR, Ramshaw IA, Snowden JM. Analysis of the inhibition of tumor metastasis by sulphated polysaccharides. Int J. Cancer 1987; 39: 82-88.

6. Ellouali $\mathrm{M}$, Boisson-Vidal $\mathrm{C}$, Durand $\mathrm{P}$, Jozefonvicz J. Antitumor activity of low molecular weight fucans extracted from Brown seaweed Ascophyllum nodosum. Anticancer Res. 1993; 13: 2011-2020.

7. Harada $H$, Noro $T$, Kamei $Y$. Selective antitumor activity in vitro from marine algae from Japan coasts. Biol. Pharm. Bull. 1997; 20: 541-546.

8. Ito $\mathrm{H}$ and Sugiura $\mathrm{M}$. Antitumor polysaccharide fraction from Sargassum thunbergii. Chem. Pharm. Bull. 1976; 24: 1114-1115.

9. Itoh $\mathrm{H}$, Noda $\mathrm{H}$, Amano $\mathrm{H}$, Zhuaug $\mathrm{C}$, Mizuno $T$, Ito $H$. Antitumor activity and immunological properties of marine algal polysaccharides, especially fucoidan, prepared from Sargassum thunbergii of phaeophyceae. Anticancer Res. 1993; 13: 2045-2052.

10. Nakanishi $\mathrm{H}$, Oguri $\mathrm{K}$, Yoshida $\mathrm{K}$, Itano N, Takenaga K, Kazama T, Yoshida A, Okayama M. Structural differences between heparan sulphates of proteoglycan involved in the formation of basement membranes in vivo by Lewis-lung- carcinoma- derived cloned cells with different metastatic potentials. Biochem. $J$. 1992; 288: 215-224.

11. Ito $H$, Wang J, Shimura $K$. Inhibition of lung metastasis by a calmodulin antagonist, $\mathrm{N}$ - ( 6aminohexyl) -5-chloro-1 - naphthalenesulfonamide ( W-7), in mice bearimg Lewis lung carcinoma. Anticancer Res. 1991; 11: 249-252.

12. Shimura $K$, Ito $H$, Hibasami $H$, Shiomi $T$, Hidaka H, Nishioka K. Enhancement of antibody-indipendent phagocytosis by $\mathrm{N}$ ( 6-aminohexyl) -5-chloro-1-naphthalene sulfonamide (W-7). Immunol. Commun. 1983; 12: 363-374.

13. Itoh $\mathrm{H}$, Ito $\mathrm{H}$, Amano $\mathrm{H}$, Noda $\mathrm{H}$. Inhibitory action of $a \quad(1 \rightarrow 6)-\beta$-D-glucan-protein complex (FIII-2-b) isolated from Agaricus blazei Murill ("Himematsutake") on Meth A fibrosarcoma-bearing mice and its antitumor mechanism. Jpn. J. Pharmacol. 1994; 66: 265271

14. Harada H, Noro $T$, Kamei $Y$. Selective antitumor activity in vitro from marine algae from Japan coasts. Biol. pharm. Bull. 1997; 20; 541-546. 